\title{
Ayurvedic Management of Mild Cognitive Impairment
}

\author{
S. Nayana and M. Jithesh
}

\begin{abstract}
Life expectancy has increased as a result of advancement in medical science. As a result the prortion of elderly in the population is also greater than ever and there is a need to tackle their problems. Mild Cognitive Impairment $(M C I)$ is one of the most common clinical manifestations affecting the elderly population. MCI is a term used to describe cognitive decline of thinking, memory and reasoning. This is an transitional stage between the cognitive decline of normal ageing and the more serious decline in dementia. Neurons fail to establish connections in appropriate time and when insufficiently stimulated by nootropic factors, they die. This gradually leads to mild cognitive impairment, as ageing occurs. According to recent published works on cognition and dementia, $2 / 3^{\text {rd }}$ of all cases who are diagnosed with MCI have memory loss, more pronounced than thinking and reasoning. Timely intervention is awfully important in these cases as they are at a high risk of developing dementia.
\end{abstract}

According to Sarangadhara Acharya, medha (grasping and retention power) deteriorates after the fourth decade of life and this may be considered as a warning signal for further smr'ti (memory) and buddhi (intellect) deterioration, in the successive years. Ayurveda has a major role to play in this arena. Rasaayana, Panchakarma therapy, drugs like guduchi, aswagandha,brahmi and the like, including various ghritas have proven effects in cognitive domains of psychological wellbeing. Further, giving constant mental stimulations through brain games which is mentioned through the concept of Buddhimedhakara gana, along with panchakarma measures, bring significant results in all domains of cognition.

Here is an attempt to discuss the pathogenesis and preventive aspects of cognitive deficits with special reference to dementia and MCI. Nootropic drugs, neuro rehabilitation and neuroplasticity are the three approaches which are analyzed in the purview of Ayurvedic concept and are suggested as techniques for the management and prevention of MCI.

Keywords--- Mild Cognitive Impairment, Dementia, Medha, Smr`ti, Nootropic Drugs, Neurorehabilitation, Neuroplasticity

\section{INTRODUCTION}

$\mathrm{M}$ ILD cognitive impairment (MCI) is the cognitive decline of thinking, memory and reasoning. Failure to recognize the onset of pathological changes of a disease from

S. Nayana., MD Scholar(Manovigyan avum Manasaroga), Department of Kayachikitsa, VPSV Ayurveda College, Kottakkal. E-mail:drnayanasivaraj@gmail.com

M. Jithesh, Associate Professor, Department of Kayachikitsa, VPSV Ayurveda College, Kottakkal.E-mail:drjitheshm@gmail.com DOI: 10.9756/BIJIEMS.8115 normal decline of function, leads to progressive disability from treatable diseases, in many cases. Normal aging and dementia are considered as two opposite ends of a continuum, and the area of transition between them has been recognized as "mild cognitive impairment". The individuals falling under the category of MCI exhibit symptoms, that lie between normal age related cognitive decline and dementia and have a very slight degree of functional impairment and minimal decline from their past level of functioning and therefore they do not meet criteria for dementia.

A longitudinal study finds the risk factors such as midlife elevated total cholesterol serum levels $(>6.5 \mathrm{mmol} / \mathrm{L})$ with systolic blood pressure, shows a trend to increase the occurrence of dementia.${ }^{[1]}$ The influence of vascular factors and diseases on the incidence of amnestic MCI sub types was analysed in 3 studies. ${ }^{[2-3]}$ Hypertension could be also identified as a risk factor.

\section{Diagnostic Criteria for MCI. ${ }^{[4]}$}

1. Presence of a cognitive complaint.

2. Absence of dementia

3. Change from normal functioning

4. Decline in any area of cognitive functioning

5. Preserved overall general functioning but possibly with increasing difficulty in the performance of activities of daily living.

2 subtypes of MCI are recognized; Amnestic (including memory impairment) and non amnestic (non memory cognitive domains impaired with the introduction of revised criteria for $\mathrm{MCI},)^{[5]}$

Diagnostic and assessment tools: The diagnosis of MCI is an opportunity for neuropsychologists to identify subtle deficit and keep an eye on cognitive status in a sequential manner, in order to determine the rate and degree of progression. Clinical and neuropsychological assessment being done in recent studies can better distinguish the MCI patients at a greatest risk for conversion to dementia. The screening measures of cognitive functioning are

1. Modified MMSE

2. Global deterioration scale

3. Barthel ADL index

4. Six letter cancellation test

5. Digit letter substitution test

6. Clock drawing test

Ayurvedic Concept of Cognition

According to Ayurveda, cognition comes under the concept of Jnanotpathi, ${ }^{[6]}$ medha, buddhi and smr ti. Jnaanotpatti involves gross objects (indriyaartha), ${ }^{[7]}$ sense organs (indriyas), ${ }^{[8]}$ buddhi, manas and atma(soul). Jnaanotpathi in- 
volves the processes of perception, attention and comprehension. This knowledge is coded in the form of memory and used for future works or decisions. Recall of old knowledge or experiences is smr ti. The normal functioning of smr ti results in buddhi.

\section{Medha}

The term medha is used in two ways viz. graham a sakthi (grasping) and dhaaran`a s`akthi (retention). ${ }^{[9]}$ Definition given by Dalhana can be evaluated as the intellectual ability to retain a large amount of knowledge for a long time. It is considered as the highest form of buddhi which acts at subtle levels ${ }^{10}$. Arunadutta considers medha as faculty of buddhi.

\section{Buddhi}

Buddhi is the discriminative psychological faculty for reasoning and logic. But after critical analysis of the classics it is evident that at many places it has been used as the advanced stage or the process leading to true knowledge. It is considered as decisive power to discriminate between good-bad and act accordingly.

\section{Smr`ti}

It is the recollection of drusht a (seen), s'ruta (heard) and anubhoota (experienced) ${ }^{[10]}$. It is used in the sense of recall.

\section{COGNITIVE IMPAIRMENT}

Atma $^{[11]}$ (soul) is adhikaran`a of jnana (substratum of knowledge $)^{[12]}$. Mind is the organ which is the instrument in obtaining the knowledge of pleasure, grief etc. When atma is covered by rajas and tamas, the recollection of the knowledge of reality is impaired, it is known as Smr tibhrams`a (derangement of memory). ${ }^{[13]}$

Manas and Indriya are also involved in the process of jnanotpatti. Manas is considered as sensory as well as motor entity. Impaired function of manas leads to false or no knowledge. ${ }^{114]}$ Impaired indriya is also responsible for the lack of knowledge. This can be explained by the fact that impaired sensory organs eg. loss/partial impairment of hearing, loss/partial impairment of vision that will interfere with process of cognition. Manas is the controller of all sense organs ${ }^{[15]}$ hence manovibhrama may also be responsible for such lack of sensory knowledge.

Chronological deterioration of cognitive function with age. According to Sarangadhara, medha (grasping and retention powers) deteriorates after the fourth decade of life and this may be considered as a warning signal for further smrti (memory) and buddhi (intellect) deterioration in the successive years. ${ }^{[16]}$

\section{CURRENT TRENDS In MCI MANAGEMENT}

Acetylcholinesterase inhibitors are widely used in the treatment of mild cognitive impairment ${ }^{[17]}$. This treatment modality does not go with the published evidences. The observations in several randomized controlled trials suggest that acetylcholinesterase inhibitors do not significantly improve cognitive function or diminish the rate of progression from MCI to dementia in patients with MCI ${ }^{[18]}$ Results from metaanalysis of these trials showed a minimal yet statistically sig- nificant reduction in the rate of progression to dementia with the use of acetylcholinesterase inhibitors for 2 years; however, this reduction was not clinically significant. ${ }^{[19]}$ The rate of adverse events were in the higher side, which included nausea, vomiting, diarrhea, muscle spasms, insomnia, abnormal dreams, headaches, peripheral edema, weight loss, syncope, fatigue, asthenia, tremors and others. ${ }^{[20]}$

In a prospective cohort, non comparative trial in people with MCI, it was found that a herbal compound, availed as dietary supplement and that contained extracts of Bacopa monnieri and Haematococcus pluvialis (astaxanthin) along with phosphatidylserine and vitamin $\mathrm{E}$ have potential for counteracting the cognitive impairment. ${ }^{[21]}$

\section{NEED FOR AN INTERVENTION IN MCI}

As an opportunity for early identification of subjects at increased risk of dementia (4-10 times higher than cognitively normal elderly persons), $\mathrm{MCI}$ is not only an important concept for epidemiologists and specialized researchers in the field of cognitive disorders, but also a clinical condition whose identification and monitoring is recommended in medical practice. Subjects with MCI constitute a population of developing dementia and is a population of clinical interest. ${ }^{[22]}$

With the increasing number of older adults, there is growing interest in improving quality of life in old age. One important aspect of this endeavor is to identify the individuals at an earlier point in the cognitive decline such that therapeutic interventions can be aimed at this juncture. Clinical trials are being conducted on MCI worldwide, but an effective pharmaceutical management is not present till date. The underlying principle for intervention in MCI is evolved from the assumption that the sooner one intervenes in a degenerative process, the less likely is the damage to the central nervous system . So, early diagnosis and treatment becomes a key factor in the prevention of subsequent disability like dementia.

\section{AYURVEDIC APPROACH IN THE PREVENTION AND PROGRESSION OF MCI}

Ayurveda the life science has a major role to play in this arena. Rasaayana, Panchakarma therapy, pranaayaama, yoga and the concept of buddhimedhaakaragan a are the Ayurvedic treatment modalities suitable to check MCI. A total cognitive rehabilitation has to be the treatment or preventive strategy. For attaining cognitive rehabilitation, the Ayurvedic modalities may be categorized under 3 main domains viz.

$\begin{array}{ll}\text { 1. } & \text { Nootropic drugs } \\ \text { 2. } & \text { Neuroplasticity } \\ \text { 3. } & \text { Neurorehabilitation }\end{array}$

\section{Nootropic Drugs}

Rasaayana is a very broad concept which mainly provides rejuvenation methods. Medhya Rasaayana is a special group of drugs which have exclusive nootrophic activity, stimulating brain functioning.

- Centella asiatica juice

- Glycirriza glabra powder with milk 
- Tinospora cordifolia paste

- Clitoria ternatea paste are used for internal administration

Apart from these, drugs like brahmi, vacha, jadamanchi, aswagandha etc has also effect in cognitive enhancement.

Sarangadhara has also mentioned certain remedies to combat with the bio loss occuring in the chronological order. He have mentioned sankhapushpi and brahmi to check the medhaanaas`a occuring in the fourth decade of life. Brahmi and Mandukaparni has been suggested for the Budhinaas`a occurring in the nineth decade of life ${ }^{[24]}$ Guduchi satva is effective in preventing the progression of MCI through enhancement of cognitive faculties. ${ }^{[25]}$ Polyherbal preparation of ghee like Naladaadi ghrita, Kalyaanaka ghrita etc has proven nootropic action. ${ }^{[26]}$

\section{Neuroplasticity}

Ability of the brain to contour itself, according to experience is termed as neuroplasticity. It is a physical change on a neuronal level due to practices and behavior. The concept of buddhimedhaakara gan`a which includes the attributes viz continuous learning, engaging in debates, studying other sciences, learning from experts. These approaches can be streamlined to the new vistas like brain games, new language learning, learning musical instrument ${ }^{27]}$, cross words etc which increases neuroplasticity ${ }^{[28]}$, thereby enhancing cognitive abilities etc. These techniques help to improve the cognitive plasticity of middle aged group and patients with MCI. The new neuronal networks which are stimulated by these methods help to improve the cognitive function, thus by preventing the occurrence of dementia like serious conditions.

\section{Neurorehabilitation}

Selective panchakarma therapy avoiding the drastic sodhana practices like vamana and virechana should be used as neurorehabilitation. The procedures in the elderly consist of snehapaana with medicated ghee especially, naladadi grita, brahmi grita according to condition, followed by swedana (sudation). Sirovasti and sirodhaara with suitable tailas like ksheerabala, dhaanwanthara taila etc are efficient for neuro regeneration and for stress relief. Sirodhaara with kwaatha of amalaki, musta etc is also effective. Nasya shows remarkable effects in improving higher mental functions. It has been mentioned as a daily regimen with lower doses (pratimars`a nasya) for intellectual excellence. Nasya is usually done with ksheerabala taila in mild cases as preventive.

The concept of aachara rasaayana can be incorporated in this domain as a neuro rehabilitation technique, which is a vitalizer of both psyche and soma. These are

- Socio-behavioural conducts for moral or mental hygiene

- Effective preventive principles for psychological disorders
Table 1: Categorization of Ayurvedic Treatment Modality for MCI

\begin{tabular}{|l|l|}
\hline Treatment aspect & Preventive aspect \\
\hline $\begin{array}{l}\text { Nootropic drugs-medhya } \\
\text { rasaayana }\end{array}$ & $\begin{array}{l}\text { Adoption of good behavioral conducts - } \\
\text { achara rasaayana }\end{array}$ \\
\hline Brain exercises & Timely intervention of lifestyle diseases \\
\hline Pancakarma procedures & Periodic intake of medhya rasaayana \\
\hline & $\begin{array}{l}\text { Active involvement in intellectually } \\
\text { stimulating activities, yoga }\end{array}$ \\
\hline
\end{tabular}

\section{CONCLUSION}

Promotion of mental health is the need of the hour. MCI management and prevention has to be given due importance as MCI may progress to more grave and irreversible condition like Alzheimer's disease. Ayurveda considers ageing as an inevitable part of life which can be delayed and its ill effects can be minimized by use of preventive measures in daily routine, specific procedures in seasonal regimen, dietary changes and behavioral codes. Specific therapeutic interventions like rejuvenation are also mentioned to tackle with all the problems. Gradual loss of functional ability of all systems along with impairment in cognition is described in various texts. Medhya drugs are described for enhancement of cognition as well as they act on psychological co-morbidities like agitation, stress and depression. Ayurveda has the potential to tackle this problem of neurodegeneration and its effects on cognition, thereby enhancing the Quality of life of a person.

\section{REFERENCES}

[1] Kivipelto M, Helkala EL, Hanninen T et al., Midlife vascular risk factors and late life mild cognitive impairment-A population based study Neurology 56,Pp 1683-9,2001

[2] Solfrizzi V, Panza F, Colacicco AM, Dintrono A, Capurso C, Torres F, et al., Italian Longitudinal study on Aging Working Group: Vascular risk factors, incidence of MCI, and rates of progression to dementia. Neurology vol 63, Pp. 1882-1891, 2004.

[3] Manly JJ, Tang MX, Schupf N, Stern Y, Vonsattel JPG, Mayeux R, Frequency and course of mild cognitive impairment in a multiethnic community, Ann neurol, 63,Pp. 494-506,2008.

[4] Winblad B,Palmer K,Kivipelto M,Jelic V,Fratigiloni L, Wahlund L O Et Al,. "Mild Cognitive Impairment-Beyond Controversies, Towards A Consensus", J Intern Med, 2004.

[5] Mueller Sg, Weiner Mw,Thal Lj,Et Al., The Alzheimer's Disease Neuro imaging Initiative In:Pettrella J R, Doraisamy P M, Editors. Neuro imaging Clinics Of North America: Alzheimer's Disease-100 Years Of Progress. Philadelphia, Penn Elsevier Saunders,Pp.869-877,2005

[6] 6.Sharma $\mathrm{P}$ V,Editor, Caraka Samhita Su 8/16,Vol 1, Varanasi Chaukhambha Orientalia,Pp.55,2007

[7] Sharma PV,Editor, Caraka Samhita Varanasi:Chaukhambha Orientalia, Vol 1, su 8/11, 2007.

[8] Sharma PV, Editor, Caraka Samhita Varanasi: Chaukhambha Orientalia, Vol 1, su 8/8, 2007.

[9] Acharya Jt,Dalhana Commentary,Editor,Susruta Samhita Of Susruta Su2/3,Varanasi:Chauhamba Surbharti Prakashan, Pp.10,2003.

[10] SarmaPv,Editor.Susruta Samhita,Varanasi: ChaukhambaBharti Academy, Vol2, Chi28/1 Dalhana Commentary, Pp.531, 2010.

[11] Sharma PV,Editor, Caraka Samhita Varanasi:Chaukhambha Orientalia, Vol 1, sha 1/149,Pp.410, 2007.

[12] Virupakshananda s, Tarka-Sangraha, Chennai Ramakrishna Math $2^{\text {nd }}$ ed, , 2/8,Pp.49, 2010.

[13] Sharma PV,Editor. Caraka Samhita, Varanasi:Chaukhambha Orientalia Vol 1, sha1/101.Pp.406, 2007

[14] Sharma PV,Editor. Caraka Samhita.Vol 1.Varanasi:Chaukhambha Orientalia,sha1/18,Pp.398, 2007.

[15] Sharma PV,Editor, Caraka Samhita Varanasi:Chaukhambha Orientalia, Vol 1, su 12/8, 2007. 
[16] Singh A H Narasimha Moorthy K,Singh G,neuronutrient impact of Ayurvedic therapy in brain aging.biogerontology,vol 9,issue (6),Pp.369374, 2008

[17] Russ TC1, Morling JR, Cholinesterase inhibitors for mild cognitive impa9:CD009132. Doi,pub2, Sep 12,2012

[18] Roberto Raschetti ,Emiliano Albanese,Nicola Vanacore,Marina Maggini ,Cholinesterase Inhibitors in Mild Cognitive Impairment: A Systematic Review of Randomised Trials ,PLOS, DOI: 10.1371/journal.pmed. 0040338, November 27, 2007

[19] B M McGleenon, K B Dynan, and A P Passmore,Acetylcholinesterase inhibitors in Alzheimer's disease, Br J Clin Pharmacol.; 48(4), Oct 1999

[20] Tom C Cruss, Cholinesterase inhibitors should not be used in MCI, Evidence Based Medicine 2014,vol 19, iss 3,2014

[21] Danilo Zanotta, Silvana Puricelli, and Guido Bonoldi, Cognitive effects of a dietary supplement made from extract of Bacopa monnieri, astaxanthin, phosphatidylserine, and vitamin $\mathrm{E}$ in subjects with mild cognitive impairment: a noncomparative, exploratory clinical study, Neuropsychiatr Dis Treat. 2014; 10: 225-230, 3. doi: 10.2147/NDT.S51092, PMCID: PMC3921088,vol 10,2014

[22] Espinosa A, Alegret M, Valero S, Vinyes-Junqué G, Hernández I, Mauleón A, Rosende-Roca M, Ruiz A, López O, Tárraga L, Boada M (2013) ,A longitudinal follow-up of 550 mild cognitive impairment patients: Evidence for large conversion to dementia rates and detection of major risk factors involved, JAD,vol 49,iss 4,5 March 2013

[23] Olga Benešová, Neuropathobiology of Senile Dementia and Mechanism of Action of Nootropic Drugs ,Review Article Clinical Pharmacology,Drugs \& Aging April 1994, Volume 4, Issue 4, Pp 285303, 2012

[24] Singh A H Narasimha Moorthy K,Singh G,neuronutrient impact of Ayurvedic therapy in brain aging.biogerontology,vol 9,issue (6),Pp.369374,2008

[25] Dr. Jadhav Avinash Bhagvat Rao ,Preventive trial on progression of mild cognitive impairment through cognitive enhancement by guduchi satva ,2014

[26] Dr.M S Baghel et al .,Clinical efficacy of Guduchyadi Medhya Rasayana on Senile Memory Impairment, Ayu,Apr-Jun; 33(2): 202208,2012

[27] Sibylle C. Herholz,Robert J. Zatorre, Musical Training as a Framework for Brain Plasticity: Behavior, Function, and Structure Volume 76, Issue 3, p486-502, 8 November 2012 